\title{
Crítica a la raó civilitzatòria: estratègies de producció de les marginalitats*
}

\author{
Carlos del Valle-Rojas \\ UNIVERSIDAD DE LA FRONTERA \\ carlos.delvalle@uufrontera.cl \\ ORCID: 0000-0002-9905-672X
}

Rebut: 06/02/2019

Acceptat: 01/10/2019

\section{RESUM}

La distinció radical entre civilització i barbàrie empleada en el discurs dels estats nacionals de Xile i l'Argentina durant la segona meitat del segle XIX no només es va utilitzar per a justificar la intervenció militar genocida als territoris habitats pels indígenes maputxes al sud d'ambdós països, sinó que també va inaugurar una relació conflictiva que es manté fins a l'actualitat. L'objectiu principal de l'article és identificar els assoliments del «projecte civilitzatori» iniciat durant la segona part del segle XIX i expressat durant els segles XX i XXI per mitjà de formes de marginalització diferents i àmplies, tant d'allò ètnic com, per extensió, d'allò immigrant, allò delictiu i dels col-lectius LGBT+. Es tracta d'un procés històric, sistemàtic i institucionalitzat de produir marginalitats, que considera diverses estratègies de producció de l'enemic íntim, especialment des de la indústria cultural disponible en cada època. Els resultats evidencien com es produeix i reprodueix el «marginal/marginalitzat», per mitjà de polítiques de mort, de despullament, d'inclusió i exclusió, en una relació constant des de racionalitats morals, criminals i neoliberals.

Paraules clau: projecte civilitzatori, crítica a la raó moral i civilitzatòria, producció de les marginalitats.

\begin{abstract}
A Critique of Civilizing Rationality: Marginality Production Strategies
The radical distinction between civilization and barbarism used in the discourse of the national states of Chile and Argentina during the second half of the XIX century, not only was used to justify the genocidal military intervention of the territories inhabited by the mapuche indigenous from the south of both countries; but also inaugurated a conflictive relationship that remains to the present. The main objective of the paper is to identify the scope of the "civilization project" initiated during the second part of the 19th century and expressed during the 20th and 21 st centuries through different and broad forms of marginalization, both ethnic and -by extension-immigrant, the criminal and LGBT+ groups; in such a way that it is a historical, systematic and institutionalized process of producing marginalities, which considers various production strategies of the intimate enemy, especially from the cultural industry available in each time.
\end{abstract}

The results show how "marginal/marginalized" is produced and reproduced, through policies of death, dispossession, inclusion/exclusion, in a constant relationship from moral, criminal and neoliberal rationalities.

Keywords: civilization project, critique of moral and civilizing reason, production of the marginalities.

\footnotetext{
* El projecte CONICYT-Chile PIA/ANILLOS SOC180045 i el projecte CONICYT-Chile FONDECYT 1150666 financen aquest treball.
} 


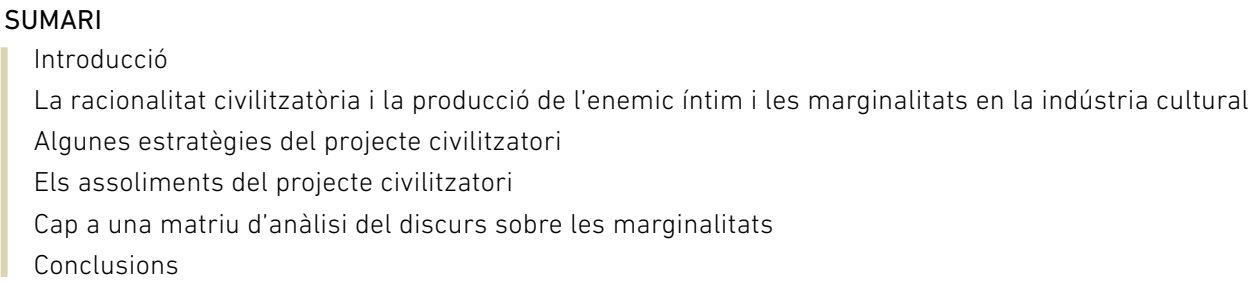

Autor per a correspondència / Corresponding author: Carlos Del Valle-Rojas. Departamento de Lenguas, Literatura y Comunicación. Facultad de Educación, Ciencias Sociales y Humanidades (Universidad de la Frontera) Francisco Salazar 01145 (Temuco-Xile).

Citació suggerida / Suggested citation: Del Valle-Rojas, C. (2019) Crítica a la raó civilitzatòria: Estratègies de producció de les marginalitats. Debats. Revista de cultura, poder i societat, 133(2), 71-81. DOI: http://doi.org/10.28939/iam.debats.133-2.6

\section{INTRODUCCIÓ}

Quan el polític, intel·lectual i expresident argentí Domingo Faustino Sarmiento va escriure Facundo o civilización y barbarie en 1874, va produir un discurs públic i polític amb una capacitat performativa de tal densitat —semàntica i pragmàtica— que va tenir un paper determinant en la justificació dels processos d'intervenció i ocupació dels territoris indígenes del sudper part dels estats nacionals de Xile i l'Argentina. És una obra d'un profund impacte simbòlic, cultural i polític: «Facundo és el clamor de la cultura moderna contra el crepuscle feudal [...] La paraula de Sarmiento sembla que baixa d'un Sinaí» (Ingenieros, 2000: 191). I també d'un gran impacte econòmic, a causa d'allò inevitable: «interacció tròpica entre la simbolització i la producció econòmica i lingüística [perquè] la llengua i la moneda són mesures. La llengua és la mesura de les idees dels homes [...] la moneda és la mesura del valor dels objectes» (Shell, 1981: 14 i 16).

En conseqüència, l'obra de Sarmiento permet entendre, fins i tot, les relacions de conflictivitat que existeixen en l'actualitat. Això últim és, no pel seu caràcter literari —que, per cert, és propi de la «modernitat»—, sinó per la relació que manté amb la ideologia i pràctica burgesa (Rodríguez, 2003), de la qual sorgeix, amb la qual col-labora i que troba eco fins als nostres dies. Això es deu especialment a la seua capacitat per construir un marc de referència que transcendeix a la seua època, a saber, la utopia dels «subjectes lliures» —és a dir, els no bàrbars-, la consigna suposadament llibertària dels quals encobreix el desig d'intercanvi de la força de treball, que és la base del projecte civilitzatori (Del Valle, 2018b). Sarmiento retrata perfectament el fonament racial de la seua obra:

El desenvolupament de la raó segueix les mateixes regles. Els salvatges tenen tots el crani de la mateixa grandària i pensen tots el mateix; és a dir, no pensen, sinó que senten. En l'estat de barbàrie ja es diferencien els cranis i comença a haver-hi opinions, és a dir, hi ha uns pocs que comencen a dubtar d'alguna cosa [...] Un llac de sang serà necessari omplir per acostar d'igual a igual aquestes dues races i moltes víctimes il.lustres de la raça blanca cauran abans sota el ganivet de la vendetta de races, al crit de «que moren els fastigosos, immunds blancs!». (Sarmiento, 1915: 195 i 260)

El precedent és un exemple de les bases que s'utilitzaran per a les operacions institucionals de reducció de l'indígena a una condició merament «racial» i cultural per mitjà d'accions específiques de subs- 
titució, de manera que el projecte civilitzatori dels estats nacionals configura una acció permanent d'anul-lació, despullament i criminalització que tendirà a eliminar completament el caràcter polític d'allò indígena. Sense reconeixement polític, no hi haurà autonomia ni emancipació, perquè es perd la capacitat de negociar la realitat quotidiana i qualsevol projecte. Aquesta despolitització és la que ha permés mantenir la situació de marginalitat dels maputxes des de mitjans del segle xx.

Aquest treball presenta, en primer lloc, una aproximació teòrica i conceptual per aprofundir en la comprensió de com la racionalitat civilitzatòria ${ }^{\mathbf{1}}$ aconsegueix no només imposar-se, sinó també perdurar fins als nostres dies i, d'aquesta manera, identificar les característiques de l'operació sistemàtica, institucional i històrica que es du a terme per a la producció de l'indígena com a enemic íntim, emprant especialment discursos fabricats en la indústria cultural hegemònica (Del Valle, 2019, 2018a, 2018b, 2018c, 2017, 2016). Per últim, es proposa un model per a l'anàlisi dels discursos propis d'aquesta matriu civilitzatòria, especialitzada en la producció de marginalitats.

\section{LA RACIONALITAT CIVILITZATÒRIA I LA PRODUCCIÓ DE L'ENEMIC ÍNTIM I LES MARGINALITATS EN LA INDÚSTRIA CULTURAL}

Des de la segona meitat del segle xIX, la indústria cultural de l'època assumirà un paper fonamental en la transmissió de les idees del projecte civilitzatori de l'estat nacional, com una «veritat» que, després d'enunciar-se, ha de fer-se accessible «a totes les intel-ligències, véncer en la consciència pública les

1 Si considerem la importància de les discursivitats presents en l'anàlisi del projecte civilitzatori, la idea d'una «racionalitat civilitzatòria» permet, al meu entendre, rellevar les pretensions «il-lustrades» que els atribueixen els autors, en el sentit que allò «racional» del projecte civilitzatori justifica la «irracionalitat» de les pràctiques d'aquest; perquè només l'admissibilitat d'aquesta contradicció permet la convivència entre la massacre i la gestió, és a dir, la gestió de la massacre. resistències que les passions i els interessos revolten, fins que formen a la llarga la convicció íntima dels pobles» (Sarmiento, 1850: 64). En aquest sentit és evident la necessitat d'una articulació entre el projecte de civilització i els mitjans de difusió disponibles en l'època.

D'una banda, entendrem el projecte civilitzatori com un relat social, cultural, econòmic, polític i mediàtic, de caràcter hegemònic, el propòsit del qual és imposar — per mitjà de diferents estratègies— la ideologia d'una Amèrica del Sud blanca, masculina i il-lustrada, alhora que es constitueix — per mera contraposició- una sèrie de marginalitats (allò indígena, allò negre, allò femení, els no educats de les classes baixes, etc.). En un sentit ampli, considerem allò civilitzatori en oposició amb allò natural (Elias, 1988), on allò que civilitza i allò bàrbar constitueixen una naturalització, fetitxització o fixació d'una distinció que va sorgir com a producte de la interacció i, per tant, és una construcció eminentment social. El projecte civilitzatori és, per tant, un discurs que emana principalment d'una concepció elitista i aristocràtica de la societat, de pretensions hegemòniques.

D'aquesta manera, també és important considerar les operacions cognitives i culturals que empren els artífexs d'aquest projecte, per exemple, pel que fa al model de marcs interpretatius (Adorno, 1988). En aquesta direcció, observarem dues operacions, a saber, la semblança i l'oposició, en una lògica binària absoluta, en la qual a un dels dos termes se li atribueix una condició inferior i negativa.

El punt de partida és el pensament filosòfic grec que veia en totes les formes complexes una dualitat en la qual un element naturalment dominava l'altre: la perfecció sobre la imperfecció, la fortalesa sobre la debilitat, la virtut sobre el vici, [on] el subjecte es reconeix a ell mateix reconeixent l'altre. L'exigència de definir el caràcter de l'altre és l'autoreconeixement per part del subjecte de la necessitat de fixar els seus propis límits. Com a procés cultural, la creació de l'alteritat pareix una exigència i una inevitabilitat 
del subjecte, tant si aquest és colonitzador com si és colonitzat. Els discursos creats sobre - i pelsubjecte colonial no van nàixer només amb el desig de conéixer l'altre sinó per la necessitat de diferenciar jeràrquicament el subjecte de l'altre. (Adorno, 1988: 61 i 66)

D'altra banda, la indústria cultural (Yúdice i Miller, 2008; Horkheimer i Adorno, 2007; Zallo, 1988) correspon a qualsevol instància o entitat amb un treball orientat a la producció i reproducció d'idees i informació, tant des del punt de vista de la relació material d'intercanvi com de la relació social de sentit; d'aquesta manera, la indústria cultural inclou la producció de ficció i no ficció. En el cas de la literatura, ens interessa especialment la condició ideològica:

La literatura no ha existit sempre. Els discursos a què hui apliquem el nom de «literaris» constitueixen una realitat històrica que només [sic] ha pogut sorgir a partir d'una sèrie de condicions —així mateix històriques - molt estrictes: les derivades del grau ideològic característic de les formacions socials «modernes» $\mathrm{O}$ «burgeses» en sentit general. (Rodríguez, 2003: 5)

En el cas de la premsa, ens interessa el seu mode de producció massiva, la seua capacitat de produir i distribuir continguts simbòlics, la seua orientació als mercats de consum (lectors) i la seua funció de reproducció ideològica i social (Zallo, 1988).

Ara bé, un dels principals modes i estratègies de la indústria cultural és la producció del maputxe com a enemic íntim de l'estat nacional i com a obstacle del projecte civilitzatori. L'enemic íntim, en aquest sentit, és un tipus d'enemic construït pels estats nacionals que es caracteritza per constituir una amenaça des de dins. L'enemic íntim ha sigut abans un veí, un conterrani o un aliat, però això no importa, perquè la relació d'enemic hi preval. La fabricació d'un enemic no és només un fet social, militar i cultural, sinó també un fet polític que aconsegueix instal-lar-se com una veritable consciència institucional amb una capacitat voraç d'autoproducció que permet a l'estat nacional mantenir un paper social il.limitat i un proselitisme permanent: «Modernity, like modern science, could live with everything except an attenuated estatus and a limited, non-proselytizing social role for it» (Nandy, 1983: 102). ${ }^{2}$

Però el camí de la producció de l'enemic íntim ha sigut tan gradual com eficient. Comença amb discursos estigmatitzadors altament metafòrics i difosos a través de la indústria cultural, especialment la literatura d'elit i la premsa hegemònica. L'estigmatització sempre ha sigut una estratègia molt eficaç i eficient, especialment perquè

quan el colonitzador afirma en el seu llenguatge que el colonitzat és un dèbil, està suggerint que aquesta deficiència requereix protecció [de la mateixa manera que quan assenyala], que el colonitzat té un rerefons pervers, de mals instints, que és lladre i fins i tot un poc sàdic, està legitimant la seua Policia i el seu just rigor (Memmi, 1971: 3).

Figura 1

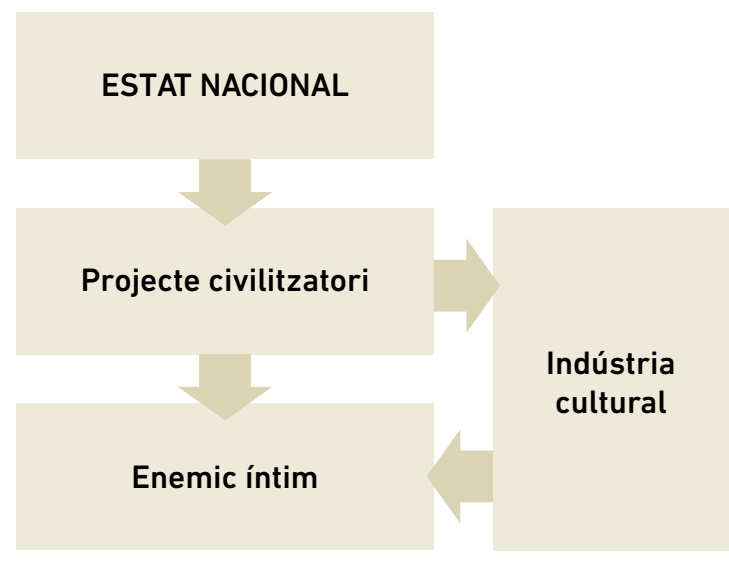

L'estratègia de producció de l'enemic (elaboració pròpia)

\section{ALGUNES ESTRATÈGIES DEL PROJECTE CIVILITZATORI}

2 «La modernitat, com la ciència moderna, pot suportar-ho tot excepte un estat atenuat i un rol social limitat, no proselitista» (nota de la traductora). 
A l'estratègia global de producció d'un enemic, el projecte civilitzatori va sumar-ne altres radicals, implementades gradualment entre els segles XIX, XX i xxi. En tots aquests casos, es tracta, en síntesi, de produir i reproduir estratègies de caràcter psicològic amb finalitats polítiques. Amb aquest objectiu, la retòrica tindrà un paper central; en el sentit d'una estratègia social

es tracta de provocar reaccions emocionals, causades per la interacció entre una sèrie d'impulsos afectius i de pressions socials [...] en difondre l'estructura, els usos i les normes socials imperants, les estratègies retòriques intervenen en la tasca de conformar, consolidar, alterar o donar cohesió al sistema dominant, per la qual cosa el seu valor pragmàtic pareix indubtable. (Galiñanes, 2009: 112)

La primera és la «necropolítica» (Mbembe, 2011), integrada per un conjunt de polítiques dissenyades i implementades pels estats nacionals durant la segona meitat del segle XIX, per mitjà de les quals es decidia qui havia de morir per consolidar el projecte civilitzatori. Aquestes decisions es vinculen amb la necessitat d'exercir la sobirania i, per tant, ens parlen també d'una manera de relació que serà constant i tindrà una matriu que s'adaptarà a certs contextos per a l'exercici del poder, on es mesclen perfectament la burocràcia i el terror de la sobirania: «Observem ací les primeres síntesis entre la massacre i la burocràcia, aquesta encarnació de la racionalitat occidental» (Mbembe, 2011: 36).

La segona estratègia és la «despullapolítica», és a dir, un conjunt de polítiques dissenyades i implementades pels estats nacionals que implica decisions sobre com traure els indígenes de les seues terres, amb el pretext que són imporoductives. D'aquesta manera, entendrem el despullament com

el procés per mitjà del qual, a partir de l'exercici de la violència o la coacció, es priva de manera permanent individus i comunitats de drets adquirits o reconeguts en la seua condició humana, en relació amb predis, propietats i drets socials, econòmics i culturals (Sánchez, 2009: 30).

Finalment, i sense perjudici de les accions descrites, la forma més eficient de política contra l'enemic íntim és projectar-ne sistemàticament la marginalitat i transformar-la en una norma. És el cas del «dret penal de l'enemic» (Jakobs i Cancio, 2003), expressió amb què es fa referència al conjunt de lleis de caràcter únic o excepcional creades i invocades especialment contra un grup de persones que -més o menys directament- no són considerades ciutadanes, sinó enemigues. El dret penal de l'enemic es caracteritza principalment perquè és prospectiu i no retrospectiu, és a dir, es refereix més a fets que podrien ocórrer i que cal «prevenir», per això les penes són elevades $i$ se suprimeixen les garanties processals.

Constitueix una reacció de combat de l'ordenament jurídic contra individus especialment perillosos [...] de forma paral-lela a les mesures de seguretat suposa tan sols un processament desapassionat, instrumental, de determinades fonts de perill especialment significatives. Amb aquest instrument, $\mathrm{l}^{\prime}$ Estat no parla amb els seus ciutadans, sinó que amenaça els seus enemics [...] la identificació d'un infractor com a enemic per part de l'ordenament penal, per més que a primera vista puga paréixer una qualificació com «una altra», no és, en realitat, una identificació com a font de perill; no suposa declarar-lo un fenomen natural que cal neutralitzar, sinó que, per contra, és un reconeixement de competència normativa de l'agent per mitjà de l'atribució de perversitat, per mitjà de la seua demonització. (Jakobs i Cancio, 2003: 86,87 i 88 )

La particularitat d'aquest dret és el moment en què emergeix, és a dir, l'instant en què els estats nacionals el generen. Aquest moment fundacional forma part d'allò que Derrida anomena «moments terrorífics», perquè solen estar acompanyats de «patiment, crims i tortures» i que esdevenen allò que Derrida (1997: 92) denomina el seu caràcter «místic»:

«És, en el dret, allò que suspén el dret. Interromp 
el dret establert per fundar-ne un altre. Aquest moment de suspens, aquesta epoché, aquest moment fundador o revolucionari del dret és, en el dret, una instància de no-dret». Ara bé, en un àmbit més específic, la producció d'allò indígena com a enemic íntim de l'estat nacional es fonamenta en una racionalitat moral, criminal i neoliberal (Misse, 2018; Vieira, 2017), és a dir, en una sèrie d'arguments pretesament racionals, basats en marcs de referència d'allò que es considera moral, normal i modern, segons el cas i l'època.

\section{Figura 2}

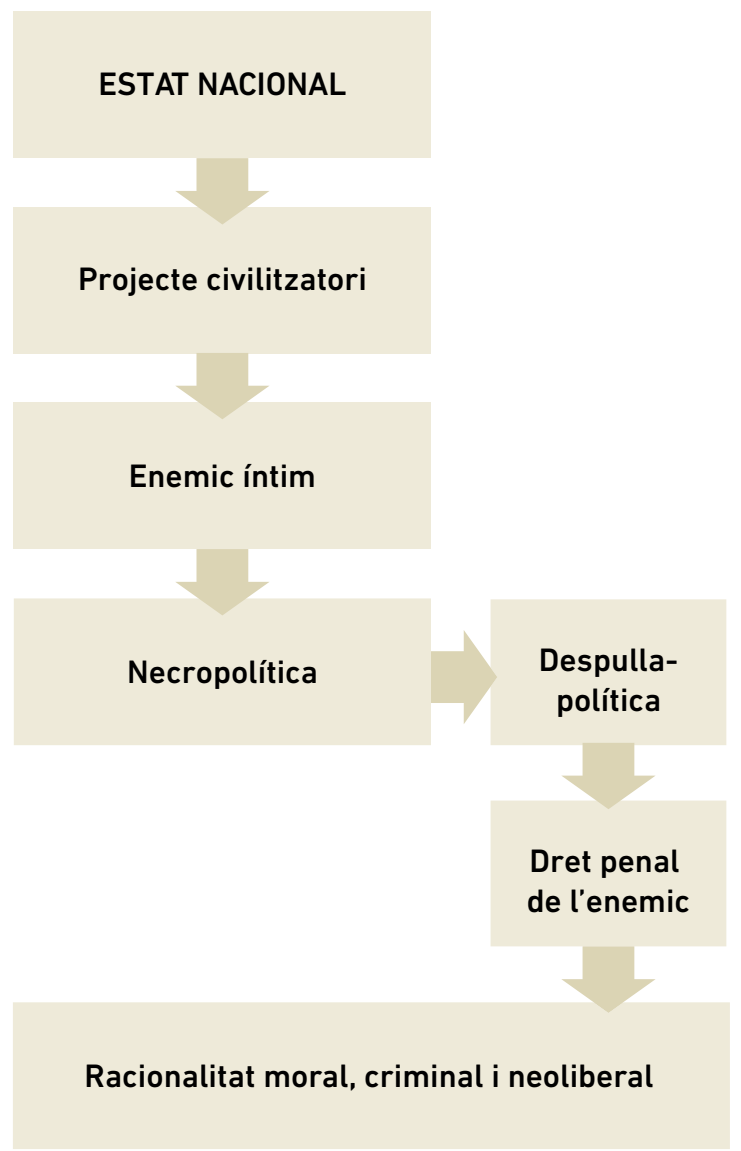

Diferents estratègies de producció de l'enemic (elaboració pròpia)

\section{ELS ASSOLIMENTS DEL PROJECTE CIVILITZATORI}

És evident que allò que es gesta a mitjan segle xIx és un projecte $\mathrm{amb}$ assoliments polítics, econòmics i militars. En Arjiropolis o la capital de los Estados confederados del Río de La Plata (1850), Sarmiento planteja els fonaments del projecte esmentat, a saber, «que la font de riquesa de tot Estat és el comerç i la indústria» i que entre les atribucions de la representació política creada es troba la de «Fer la pau i fer la guerra».

Aquest projecte de la racionalitat civilitzatòria s'estendrà en els segles següents, amb matisos, però amb una matriu fonamental, a saber, les diferents modalitats del «ser enemic» i que, al mateix temps, són formes de no ser i que, en conjunt, integren una estratègia de marginalització.

En efecte, un dels aspectes d'interés per a la investigació és comprendre com la producció històrica i sistemàtica d'allò indígena com a enemic íntim des del discurs de l'estat nacional i per mitjà de la indústria cultural aconsegueix tenir efectes no només en l'àmbit global i ampli de les relacions de les societats i cultures involucrades, sinó també en les vides quotidianes dels mateixos indígenes. En aquest sentit, sorgeix la idea de subjecció moral, criminal i neoliberal (Misse, 2018, 2014, 2010), és a dir, una condició complexa de certs grups socials i culturals en els quals una profunda intervenció -històrica, sistemàtica i institucionalitzada- podria ocasionar graus d'autoconvenciment sobre la connaturalitat de la criminalitat. No obstant això, és important considerar que el crim no existeix fora de la interacció que el produeix, de manera que és una significació moral de determinats fets i en els quals actuen certs «emprenedors morals» (Becker, 2009) o grups de poder responsables de crear les condicions necessàries perquè unes conductes, i no altres, es tipifiquen com a criminals o delictives, de manera que s'aconsegueix que aquestes se sancionen i s'etiqueten. D'aquesta manera, podem observar que el significat del crim està en permanent disputa, especialment perquè és per mitjà del procés de subjecció criminal com es produeix un subjecte criminal. 
Aquest procés té múltiples conseqüències. D'una banda, el subjecte criminalitzat reacciona igual que el subjecte colonitzat, com quan

esborrava els retrats aliens que l'identificaven amb la naturalesa, la passió, allò femení, allò domèstic, allò rústic i allò pagà, per identificar-se amb els valors contraris: la cultura, la raó, allò viril, allò públic, allò cortesà o cavalleresc, allò cristià. (Adorno, 1988: 66)

D'altra banda, la subjecció criminal, en aquest sentit, és una evidència de la lluita pel cos i la voluntat de l'altre; és el senyal d'una altra disputa, la que es refereix a la producció, reproducció i resistència enfront de la seua pròpia condició, perquè el colonitzat

segueix debatent-se contra ell. Estava escindit entre el que era i el que volia ser, i ara està escindit entre el que volia ser i allò en que ara s'està convertint. Però es manté el dolorós desfasament d'ell mateix. Perquè siga possible la curació completa del colonitzat cal que cesse completament la seua alienació: cal esperar la desaparició completa de la colonització, inclòs el temps de la rebel-lió. (Memmi, 1971: 28)

La subjecció és un fenomen complex perquè implica, d'una part, la subordinació al poder i, de l'altra, al propi subjecte; de manera que es tracta, al mateix temps, d'un poder que s'exerceix sobre un subjecte i un poder que és assumit per un subjecte.

La subjecció criminal fa referència a un procés social pel qual s'expandeix una expectativa negativa sobre individus i grups i els fa creure que aquesta expectativa no només és veritable sinó també constitutiva de la seua subjectivitat [...] el crim és reificat, encarnat en el subjecte pretés autor de crims [...] Hi ha una diferència fonamental entre un atribut desacreditador (l'estigma, l'etiquetatge, l'estereotip negatiu, el prejudici) $i$ una expectativa social que un altre vulga, o puga, intencionalment, fer el mal. Quan es tracta de definir patrons de sociabilitat, aquesta diferència té especial rellevància, perquè en el primer cas el conflicte pot resultar de l'atribut, mentre que, en el segon, l'atribut és conseqüència de l'expectativa de conflicte (Misse, 2018: 191, 192).

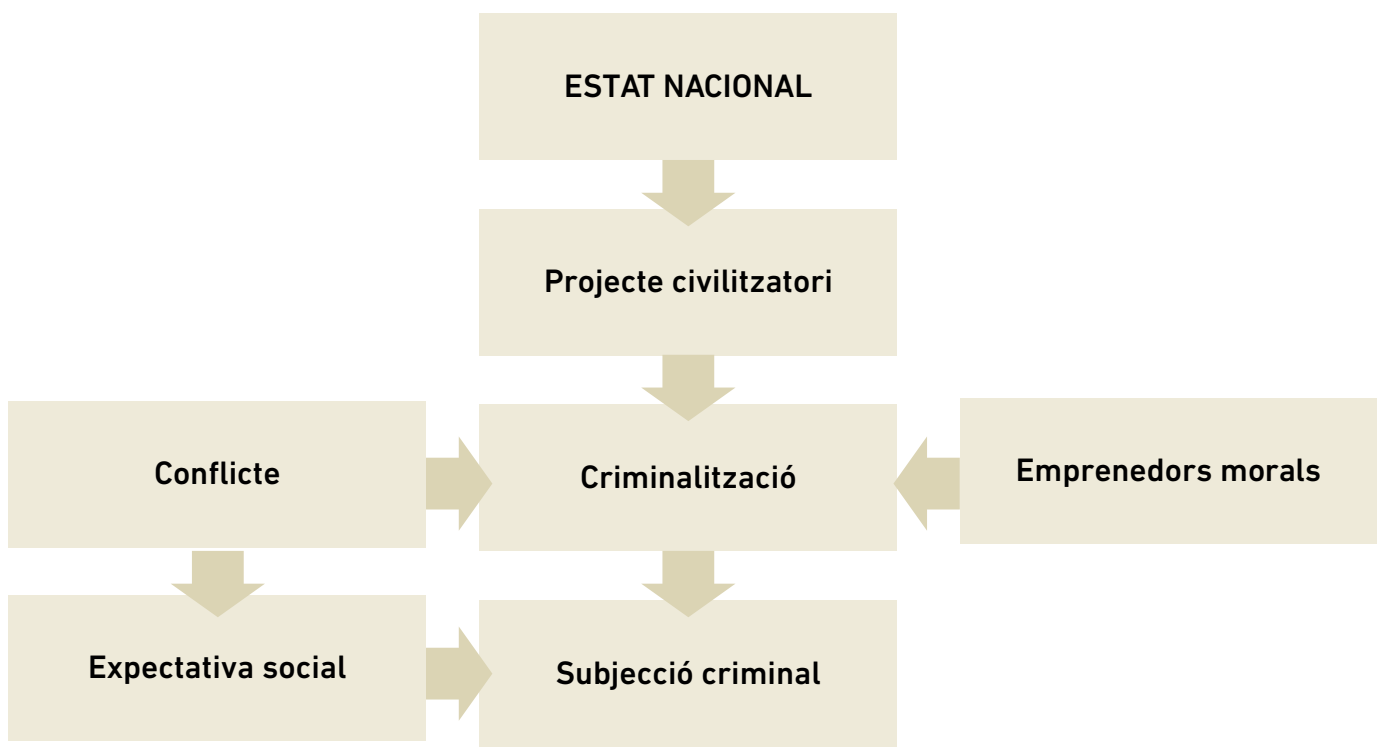




\section{CAP A UNA MATRIU D'ANÀLISI DEL DISCURS SOBRE LES MARGINALITATS}

A partir d'aquest marc teòric i conceptual específic utilitzat per a comprendre el discurs que ha produït la indústria cultural per a construir allò indígena com a enemic íntim de l'estat nacional, es proposa una matriu que permeta recollir-lo i analitzar-lo.

En primer lloc, entendrem el discurs com una pràctica social que

a) s'inscriu dins d'un procés social de producció discursiva i hi assumeix una posició determinada i per referència a aquest (interdiscurs);

b) remet implícita o explícitament a una "premissa cultural» preexistent que es relaciona amb el sistema de representacions i de valors dominants (o subalterns), l'articulació complexa i contradictòria del qual dins d'una societat defineix la formació ideològica d'aquesta societat;

c) es presenta com una pràctica socialment ritualitzada i regulada per aparells en el marc d'una situació conjuntural determinada. (Giménez, 1981: 125).

En segon lloc, dins de la indústria cultural considerarem, com hem dit, dues expressions: la literatura i la premsa. Una se centra en les literatures nacionals, que a Occident coincideixen amb la construcció política dels nacionalismes i que, a més, són hereves del mateix marc ideològic i espiritual que va donar origen a la revolució liberal i l'ordre capitalista, on la literatura nacionalista té menys relació amb l'estètica de l'art que amb la política nacionalista (Mariátegui, 2000). L'altra, la premsa hegemònica, bàsicament al-ludeix a aquella que, en coincidir amb la construcció política dels nacionalismes, s'institueix com a veu del poder, una aliada per a la socialització dels seus discursos, de manera que fins i tot intervé com un actor polític més.

En tercer lloc, assistim a l'organització de projectes culturals per part de les classes dominants, que variaran segons l'època i els interessos, i que ens permeten observar algunes continuïtats i canvis:
1) El de la cultura d'elit. S'hi reprenen velles pautes de l'aristocràcia, de la cultura de l'Antic Règim, de la cultura com a prestigi, privilegi, diferenciació, apropiació.

2) El projecte distributiu, aquell que es bolca en l'alfabetització, l'educació, part del periodisme, etcètera. Les classes dominants hi tenen per objectiu elevar el nivell cultural de les classes populars, però des dels seus interessos...

3) El que persegueix una finalitat lucrativa. Amb l'alfabetització, la concentració urbana, les reestructuracions socials i la industrialització creixen nous públics, apareix un mercat de consumidors de cultura que ofereix possibilitats per a la inversió de capitals. La cultura es transforma, així, en una branca industrial poderosa que permetrà el sorgiment de la cultura de masses (Ford, 2016: 72 i 73).

Finalment, emprarem la idea de producció de marginalitats com una manera de rellevar el caràcter performatiu del discurs, és a dir, la seua capacitat no només de referir-se a una realitat determinada, sinó de construir-la de manera arbitrària i interessada. Així, la marginalitat és el resultat d'un procés social, cultural, polític i econòmic centrat en el desig d'excloure altres grups prèviament establerts o que s'estiguen incorporant a un territori, i en aquest cas variaran les estratègies, l'ordre o la intensitat d'aquestes. Així doncs, si l'enemització i la criminalització són estratègies, la marginalitat és un resultat, perquè no n'hi ha prou amb retolar els enemics i els criminals, és necessari excloure'ls als marges de la vida social.

En aquest escenari, es planteja una matriu integrada pels conceptes anteriors, operacionalitzats com a categories per a la recol-lecció i l'anàlisi dels discursos: 


\begin{tabular}{|c|c|c|c|c|c|c|}
\hline & $\begin{array}{l}\text { Necro- } \\
\text { política }\end{array}$ & $\begin{array}{l}\text { Despulla- } \\
\text { política }\end{array}$ & $\begin{array}{l}\text { Dret } \\
\text { penal de } \\
\text { l'enemic }\end{array}$ & $\begin{array}{l}\text { Racionalitat } \\
\text { moral, } \\
\text { criminal i } \\
\text { neoliberal }\end{array}$ & $\begin{array}{l}\text { Subjecció } \\
\text { moral, } \\
\text { criminal i } \\
\text { neoliberal }\end{array}$ & Marginalitat \\
\hline $\begin{array}{l}\text { Categoria / } \\
\text { descripció }\end{array}$ & $\begin{array}{l}\text { Referència } \\
\text { explícita o } \\
\text { implícita a } \\
\text { polítiques } \\
\text { orientades a } \\
\text { l'eliminació } \\
\text { del grup. }\end{array}$ & $\begin{array}{l}\text { Referència } \\
\text { explícita o } \\
\text { implícita a } \\
\text { polítiques } \\
\text { orientades } \\
\text { a despullar } \\
\text { els grups } \\
\text { del territori. }\end{array}$ & $\begin{array}{l}\text { Referència } \\
\text { explícita o } \\
\text { implícita a } \\
\text { lleis } \\
\text { d'excepció } \\
\text { o especials } \\
\text { contra els } \\
\text { grups. }\end{array}$ & $\begin{array}{l}\text { Referència } \\
\text { explícita o } \\
\text { implícita } \\
\text { a valors } \\
\text { morals per } \\
\text { desacredi- } \\
\text { tar i } \\
\text { estigmatit- } \\
\text { zar el grup. }\end{array}$ & $\begin{array}{l}\text { Referència } \\
\text { explícita o } \\
\text { implícita } \\
\text { a arguments } \\
\text { morals i } \\
\text { persuasius } \\
\text { contra } \\
\text { el grup. }\end{array}$ & $\begin{array}{l}\text { Referència } \\
\text { explícita o } \\
\text { implícita a } \\
\text { la condició } \\
\text { d'exclusió } \\
\text { del grup. }\end{array}$ \\
\hline
\end{tabular}

Matriu d'anàlisi del discurs de l'enemic íntim i el subjecte criminal (elaboració pròpia)

\section{CONCLUSIONS}

El propòsit del treball ha sigut aproximar-se de manera teòrica i conceptual a un fenomen històric, sistemàtic i institucionalitzat de producció de la marginalitat dels indígenes, però que, per extensió, ens permet comprendre l'exclusió d'altres grups en l'actualitat, com els immigrants, els reus i els diferents col-lectius LGBT+. Aquests grups formen part de la nostra investigació, fins i tot des d'una perspectiva multipaís, com és el cas del projecte d'investigació en Ciències Socials i Humanitats «Converging Horizons: Production, Mediation, Reception and Effects of Representations of Marginality» (SOC180045), actualment en curs a Xile, l'Argentina i el Brasil.

Les estratègies que hem observat des del segle xIx fins a l'actualitat comprenen l'aplicació de polítiques de mort, polítiques de despullament o polítiques de criminalització per mitjà de lleis especials que configuren un dret penal de l'enemic. Això és possible perquè el projecte civilitzatori, si bé pareix tenir un origen clar, encara es manté en les nostres societats sota la forma d'un relat social, cultural, econòmic, polític i mediàtic que té un caràcter hegemònic i l'objectiu del qual —sempre vigent- és imposar, per mitjà de diferents estratègies, la ideologia d'una Amèrica del Sud blanca, masculina i il-lustrada, alhora que produeix -i per mera contraposició- una sèrie de marginalitats (allò indígena, allò negre, allò femení, els no educats de les classes baixes, etc.).

Es tracta, per cert, de problemàtiques que tenen vigència, necessitat i interés permanent per a la investigació social. Bàsicament, perquè la presència de grups socioculturals múltiples i variats - característica de les societats complexes actuals-, sumada al paper actiu d'una indústria mediàtica que posa en joc certes representacions interessades dels grups, genera, en conjunt, processos d'incertesa social que produeixen «dubtes profunds sobre qui exactament es troba dins del nosaltres i qui dins de l'ells». Tant és així que les diverses pràctiques de marginalització i exclusió que observem constitueixen formes d'enfrontar aquesta incertesa «desmembrant el cos sospitós, el cos sota sospita» (Appadurai, 2007; p. 18).

En definitiva, fins ara bàsicament hem vist com es produeix i reprodueix els subjectes «marginals o marginalitzats» utilitzant diverses estratègies psicopolítiques des de racionalitats morals, criminals i neoliberals imposades per certs grups de la societat amb l'objec- 
tiu d'excloure'n altres. Queda pendent conéixer les característiques de les estratègies actuals, presents tant en les pràctiques socials dels grups com en el discurs de la indústria mediàtica, així com comprendre les interaccions entre els diferents grups, especialment en la relació entre els «establerts i marginats» (Elías i Scotson, 2016).

\section{REFERÈNCIES BIBLIOGRÀFIOUES}

Adorno, R. (1988). El sujeto colonial y la construcción cultural de la alteridad. Revista de Crítica Literaria Latinoamericana, año 14 (28), p. 55-68.

Appadurai, A. (2007). El rechazo de las minorías. Ensayo sobre la geografía de la furia. Barcelona: Tusquets Editores.

Becker, H. (2009). Outsiders: hacia una sociología de la desviación. Buenos Aires: Siglo XXI.

Del Valle, C. (2016). Genealogía crítica del conflicto entre el Estado de Chile y el Pueblo Mapuche a partir de las producciones discursivas de la prensa, las sentencias penales en los tribunales de la región de La Araucanía y otros relatos. Hacia una historiografía de la exclusión mediática y jurídico social. En J. Pinto (ed.), Conflictos étnicos, sociales y económicos en la Araucanía, 1900-2014 (p. 247-282). Santiago de Xile: Pehuén.

Del Valle, C. (2017). La producción del «enemigo interno» en la industria cultural en Chile: De la discriminación a la «sujeción criminal». En M. García i F. Maniglio (ed.), Los territorios discursivos de América Latina. Interculturalidad, comunicación e identidad (p. 8-26). Quito: Ediciones CIESPAL.

Del Valle, C. (2018a). La producción del enemigo íntimo en la industria cultural chilena: Crítica a la certeza moral, la razón neoliberal y la sujeción criminal. En D. Caldevilla (ed.), Perfiles actuales en la información y en los informadores (p. 51-68). Madrid: Serie Ediciones Universitarias Editorial TECNOS.

Del Valle, C. (2018b). La simbolización de la industria y la industrialización de la cultura, a propósito de la producción del libro en Chile. En C. Maldonado, C. Peralta, C. del Valle i Í. Salgado (ed.), Libros de la lluvia. Estado actual de las editoriales independientes y universitarias del sur de Chile. (p. 23-45). Temuco: Ediciones Universidad Católica de Temuco.

Del Valle, C. (2018c). El rol de la industria cultural en el proyecto civilizatorio: Hacia una matriz de análisis del discurso del enemigo íntimo y el sujeto criminal. En S. Poliszuk i A. Barbieri (ed.), Medios, periodismo y actores en escenarios de conflictos sociales. Río Negro: Editorial de la Universidad Nacional de Río Negro. [En premsa].

Del Valle, C. (2019). La criminalización radical del enemigo como estrategia del estado nacional y las élites en la lucha por las tierras indígenas. En Á. Arévalo, G. Vilar i M. García (ed.), Comunicación y cambio social (p. 155-165). Barcelona: Tirant lo Blanch.

Derrida, J. (1997). Fuerza de ley. El «fundamento místico de la autoridad». Madrid: Tecnos.

Elias, N. (1988). El proceso de la civilización. Investigaciones sociogenéticas y psicogenéticas. Mèxic: FCE.

Elias, N. i Scotson, J. (2016). Establecidos y marginados. Una investigación sociológica sobre problemas comunitarios. Mèxic DF: Fondo de Cultura Económica.

Ford, A. (2016). 30 años después. 1973: las clases de Introducción a la Literatura en Filosofía y Letras y otros textos y relatos. La Plata: Universidad Nacional de La Plata.

Galiñanes, M. (2009). Atrocidades, maldades, enemigos sangrientos y zahúrdas de Plutón: estrategias retóricas para la representación de la alteridad. En P. Begrand (ed.), Representaciones de la alteridad, ideológica, religiosa, humana y espacial en las relaciones de sucesos, publicadas en España, Italia y Francia en los siglos XVI-XVIII. Besançon: Presses Universitaires de Franche-Comté.

Giménez, G. (1981). Poder, estado y discurso. Perspectivas sociológicas y semiológicas del discurso político-jurídico. Mèxic: Universidad Nacional Autónoma de México.

Horkheimer, M. i Adorno, T. (2007). Dialéctica de la Ilustración. Madrid: Akal.

Ingenieros, J. (2000). El hombre mediocre. Recuperat de http://educ.ar

Jakobs, G. i Cancio, M. (2003). Derecho penal del enemigo. Madrid: Civitas Ediciones.

Mariátegui, J. C. (2000). El florecimiento de las literaturas nacionales. En A. Fernández (comp.), La invención de la nación. Lecturas de la identidad de Herder a Homi Bhabha. Buenos Aires: Ediciones Manantial.

Mbembe, A. (2011). Necropolítica seguido de Sobre el gobierno privado indirecto. Santa Cruz de Tenerife: Editorial Melusina. 
Memmi, A. (1971). Retrato del colonizado, precedido por retrato del colonizador. Madrid: Cuadernos para el diálogo.

Misse, M. (2018). Una identidad para el exterminio. La sujeción criminal y otros escritos. Temuco: Ediciones UFRO.

Misse, M. (2010). La acumulación social de la violencia en Río de Janeiro y en Brasil: algunas reflexiones. Revista Coherencia, 7(13), p. 19-40.

Misse, M. (2014). Sujeição criminal. En R. Sérgio de Lima (org.), Crime, polícia e justiça no Brasil (p. 204-212). São Paulo: Editora Contexto.

Nandy, A. (1983). The intimate enemy. Loss and recovery of self under colonialism. Oxford: Oxford University Press.

Rodríguez, J. C. (2003). El escritor que compró su propio libro. Para leer El Quijote. Barcelona: Debate.

Sánchez, G. (2009). El despojo de tierras y territorios. Aproximación conceptual. Bogotà: Área de Memoria Histórica-Comisión Nacional de Reparación y Reconciliación (CNRR).

Sarmiento, Domingo (1845). Civilización i Barbarie. Vida de Juan Facundo Quiroga. Aspecto físico, costumbres i habitos de la Republica Arjentina. Santiago: Imprenta del Progreso.

Sarmiento, D. (1915). Conflicto y armonías de las razas en América. Buenos Aires: La Cultura Argentina.

Sarmiento, D. (1850). Arjiropolis o la capital de los Estados confederados del Río de La Plata. Solución de las dificultades que embarazan la pacificación permanente del río de La Plata, por medio de la convocación de un Congreso, y la creación de una capital en la isla de Martín García, de cuya posesión (hoy en poder de la Francia) dependen la libre navegación de los ríos, y la independencia, desarrollo y libertad del Paraguay, el Uruguay y las provincias argentinas del litoral. Santiago de Xile: Imprenta de Julio Belin i Ca.

Vieira, E. (2017). Teoria psicopolítica. A emancipação dos aparelhos psicopolíticos da cultura. Temuco: Ediciones UFRO.

Yúdice, G. i Miller, T. (2008). O copyright: Instrumento de expropriação e resistência onde se encontram a economia política e os estudos culturais. En C. Bolaño (org.), Comunicação e a crítica da economia política. Perspectivas teóricas e epistemológicas (p. 173-191). São Cristóvão: Editora UFS.

Zallo, R. (1988). Economía de la comunicación y la cultura. Madrid: Akal.

\section{NOTA BIOGRÀFICA}

Professor titular A, Universidad de La Frontera, Xile. Research Fellow, University of Groningen, Països Baixos. Doctor en comunicació, Universidad de Sevilla, Espanya. Postdoctorat del Programa Avançat de Cultura Contemporània, Universidade Federal do Rio de Janeiro, Brasil. Director del doctorat en comunicació i director de la revista Perspectivas de la comunicación, Universidad de La Frontera, Xile. 